\title{
PREPARATION AND BIOLOGICAL ACTIVITIES OF 10-DECARBAMOYLOXY-9-DEHYDROMITOMYCIN B AND ITS ANALOGS
}

\author{
Chikahiro Urakawa, Haruko Tsuchiya and Kin-ichi Nakano \\ Tokyo Research Laboratory of Kyowa Hakko Kogyo Co., Ltd. \\ 3-6-6 Asahimachi, Machidashi, Tokyo, Japan 194
}

\section{NOBUO NAKAMURA*}

Pharmaceutical Research Laboratories of Kyowa Hakko Kogyo Co., Ltd. 1188 Shimotogari, Nagaizumicho, Suntogun, Shizuoka, Japan 411

(Received for publication April 27, 1981)

\begin{abstract}
A new naturally occurring mitomycin, 10-decarbamoyloxy-9-dehydromitomycin B (1), was prepared by treating mitomycin B with sodium hydride. Its analogs having an exo-cyclic double bond in their structure were also synthesized. These compounds showed antibacterial and cytotoxic activities. Among them, 7-amino-10-decarbamoyloxy-9-dehydro-7-demethoxymitomycin B (2) was the most potent growth inhibitor of $\mathrm{KB}$ cells in vitro and, accordingly, it appears to be a potential antitumor agent.
\end{abstract}

It has previously been reported ${ }^{1)}$ that new mitomycin, 10-decarbamoyloxy-9-dehydromitomycin B (1), was isolated from a mitomycin B rich fraction of the mitomycin fermentation products of Streptomyces caespitosus. It was the first example of a mitomycin differing from hitherto known naturally occurring mitomycins by having an exo-cyclic double bond in its structure. The present paper describes the preparation and biological evaluation of $\mathbf{1}$ and its analogs. These compounds were prepared because we were interested in the mode of action of mitomycin antibiotics ${ }^{2)}$ and also wished to study the chemical conversion of a naturally occurring mitomycin to compound $\mathbf{1}$.

\section{Chemistry}

Compound 1 and its analogs were prepared from mitomycin B as shown in Fig. 1. Bluish needles were obtained by treating mitomycin B with an excess of sodium hydride or potassium tert-butoxide in tetrahydrofuran, followed by purification. The compound obtained was identified as $\mathbf{1}$ by PMR, IR, TLC and mass spectrum. The yield was $5 \sim 10 \%$ from mitomycin B.

The similar treatment of 7-amino-7-demethoxymitomycin $\mathrm{B}^{3)}$ gave 7-amino-10-decarbamoyloxy-9dehydro-7-demethoxymitomycin B (2) in a $10 \sim 20 \%$ yield. Since tar-like by-products formed in these reactions, an appropriate amount of silica gel was added in the reaction system to adsorb the tar. Under these conditions 1 and 2 were obtained in $17.0 \%$ and $42.8 \%$ yield, respectively. The difference between the yields might be due to the difference in the stability of 7-methoxymitosane and 7-aminomitosane.

Mitosane structure is known to be fairly stable under basic conditions. For instance, hydrolysis ${ }^{3)}$ of the 7-amino or 7-methoxy group, aminolysis ${ }^{3)}$ or alcoholysis ${ }^{4)}$ of the 7-methoxy group and decarbamoylation $^{5)}$ of the urethane group can be carried out with retention of the mitosane structure. In the present case the reaction conditions were basic and the removal of carbamoyloxy group probable pro-

* Present address: Kyowa Hakko Kogyo Co., Ltd., 1-6-1 Otemachi, Chiyodaku, Tokyo, Japan 100 
Fig. 1 .
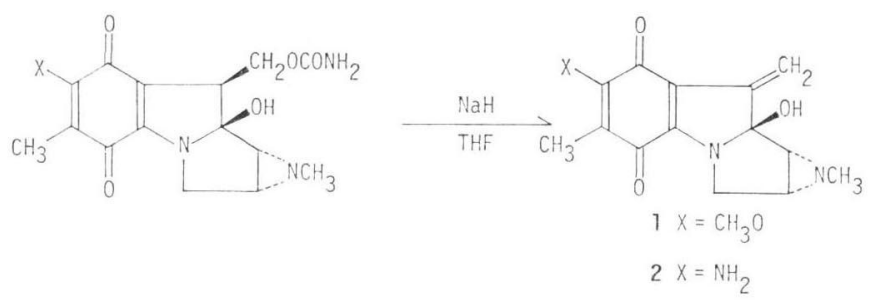

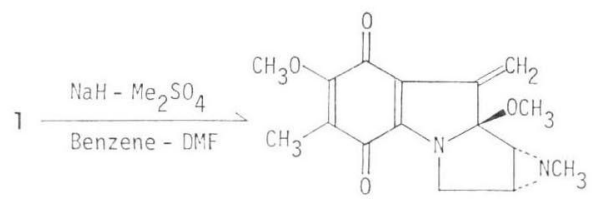

3

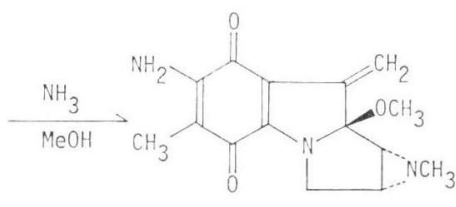

4

Fig. 2.

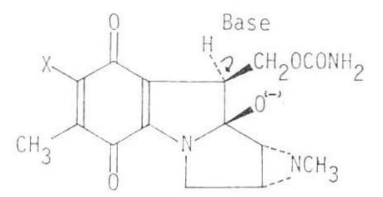

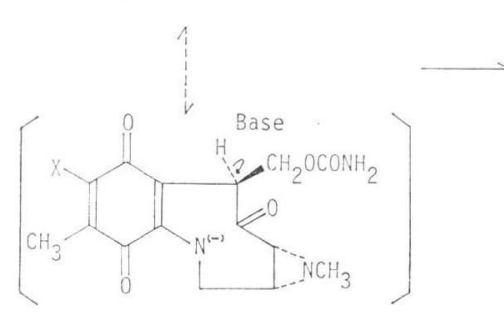

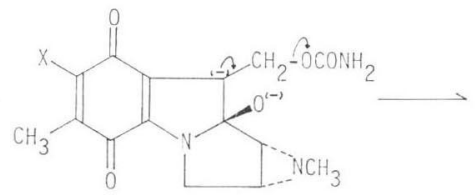

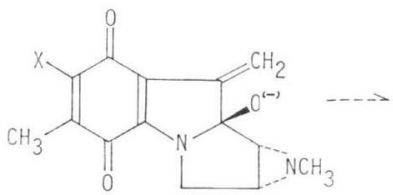

ceeds as shown in Fig. 2. As a result, carbamic acid was lost from the parent compound. On the other hand, mitomycins A, C and porfiromycin and $N$-methylmitomycin A having 9a-methoxy group in their structures did not react under similar condition.

Methylation of $\mathbf{1}$ with dimethyl sulfate in the presence of sodium hydride gave 10-decarbamoyloxy9-dehydro- $N$-methylmitomycin A (3) in a $41.5 \%$ yield, which was converted to 10 -decarbamoyloxy-9dehydroporfiromycin (4) in a $65.2 \%$ yield by treatment with methanolic ammonia.

The spectral properties of all the four compounds were consistent with their assigned structures. Thus, compound 1 and its analogs were obtained from mitomycin B.*

\section{Biological Activities}

Antibacterial activities of compounds $\mathbf{1} \sim \mathbf{4}$ are shown in Table 2 expressed in minimum inhibition

* While we had been working on the compounds described in this paper, we received a personal communication from Dr. Y. KIsHI at the Harvard University that he prepared 3.

Compounds 3 and 4 were found in Streptomyces caespitosus broth by another group in our laboratory. A paper concerning these compounds was presented at the 23rd Symposium on the Chemistry of Natural Products (Nagoya, Japan, October 22 25, 1980) by K. Shirahata, M. Kono, I. Matsubara and M. Kasai, entitled "New mitomycins, structure determination, derivation and their anticancer activity". 
Table 1. ${ }^{1} \mathrm{H}$ Chemical shifts of 10-decarbamoyloxy-9-dehydromitomycin B and its analogs.*

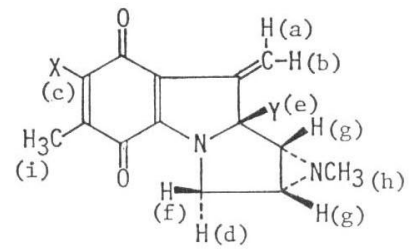

\begin{tabular}{|c|c|c|c|}
\hline & $\mathrm{X}$ & $\mathrm{Y}$ & $\delta$ from TMS as internal standard \\
\hline 1 & $\begin{array}{l}\mathrm{CH}_{3} \mathrm{O} \\
\left(\mathrm{CDCl}_{3}\right)\end{array}$ & $\mathrm{OH}$ & $\begin{array}{l}\text { (a) } 6.13(1 \mathrm{H}, \mathrm{s})(\mathrm{b}) 5.53(1 \mathrm{H}, \mathrm{s})(\mathrm{c}) 4.05(3 \mathrm{H}, \mathrm{s})(\mathrm{d}) 3.98(1 \mathrm{H}, \mathrm{d}, J=13 \mathrm{~Hz}) \\
\text { (e) } 3.00 \sim 4.20(1 \mathrm{H}, \text { broad) (f) } 3.45(1 \mathrm{H}, \mathrm{d}, J=13 \mathrm{~Hz})(\mathrm{g}) 2.27(2 \mathrm{H}, \mathrm{s}) \\
\text { (h) } 2.18(3 \mathrm{H}, \mathrm{s})(\mathrm{i}) 1.75(3 \mathrm{H}, \mathrm{s})\end{array}$ \\
\hline & $\begin{array}{l}\mathrm{NH}_{2} \\
\mathrm{O}-d_{6}-\mathrm{CDC}\end{array}$ & $\underset{\left(I_{3}\right)}{\mathrm{OH}}$ & $\begin{array}{l}\text { (a) } 5.90(1 \mathrm{H}, \mathrm{s})(\mathrm{b}) 5.32(1 \mathrm{H}, \mathrm{s})(\mathrm{c}) 6.47(2 \mathrm{H}, \mathrm{bs})(\mathrm{d}) 4.22(1 \mathrm{H}, \mathrm{d}, J=13 \mathrm{~Hz}) \\
\text { (e) } 6.33(1 \mathrm{H}, \mathrm{s})(\mathrm{f}) 3.43(1 \mathrm{H}, \mathrm{d}, J=13 \mathrm{~Hz})(\mathrm{g}) 2.23(2 \mathrm{H}, \mathrm{s})(\mathrm{h}) 2.17(3 \mathrm{H}, \mathrm{s}) \\
\text { (i) } 1.70(3 \mathrm{H}, \mathrm{s})\end{array}$ \\
\hline 3 & $\begin{array}{l}\mathrm{CH}_{3} \mathrm{O} \\
\left(\mathrm{CDCl}_{3}\right)\end{array}$ & $\mathrm{OCH}_{3}$ & $\begin{array}{l}\text { (a) } 6.32(1 \mathrm{H}, \mathrm{s})(\mathrm{b}) 5.50(1 \mathrm{H}, \mathrm{s})(\mathrm{c}) 4.08(3 \mathrm{H}, \mathrm{s})(\mathrm{d}) 4.08(1 \mathrm{H}, \mathrm{d}, J=13 \mathrm{~Hz}) \\
\text { (e) } 3.07(3 \mathrm{H}, \mathrm{s}) \text { (f) } 3.41(1 \mathrm{H}, \mathrm{dd}, J=1.5 \mathrm{~Hz}, J=13 \mathrm{~Hz})(\mathrm{g}) 2.25(2 \mathrm{H}, \mathrm{bs}) \\
\text { (h) } 2.22(3 \mathrm{H}, \mathrm{s})(\mathrm{i}) 1.85(3 \mathrm{H}, \mathrm{s})\end{array}$ \\
\hline 4 & $\begin{array}{l}\mathrm{NH}_{2} \\
\left(\mathrm{CD}_{3} \mathrm{OD}\right)\end{array}$ & $\mathrm{OCH}_{3}$ & $\begin{array}{l}\text { (a) } 6.08(1 \mathrm{H}, \mathrm{d}, J=0.7 \mathrm{~Hz})(\mathrm{b}) 5.34(1 \mathrm{H}, \mathrm{d}, J=0.7 \mathrm{~Hz})(\mathrm{c}) 4.81(2 \mathrm{H}, \mathrm{s} \text {, as } \\
\left.\mathrm{CD}_{3} \mathrm{OH}\right)(\mathrm{d}) 4.26(1 \mathrm{H}, \mathrm{d}, J=13.1 \mathrm{~Hz})(\mathrm{e}) 3.06(3 \mathrm{H}, \mathrm{s})(\mathrm{f}) 3.43(1 \mathrm{H}, \mathrm{dd} \\
J=1.3 \mathrm{~Hz}, J=13.1 \mathrm{~Hz})(\mathrm{g}) 2.43(2 \mathrm{H}, \mathrm{bs})(\mathrm{h}) 2.21(3 \mathrm{H}, \mathrm{s})(\mathrm{i}) 1.77(3 \mathrm{H}, \mathrm{s})\end{array}$ \\
\hline
\end{tabular}

* 1 3: Varian T-60 spectrometer

4: JEOL FX-100 NMR spectrometer

Table 2. Antibacterial activity of 10-decarbamoyloxy-9-dehydromitomycin B and its analogs.

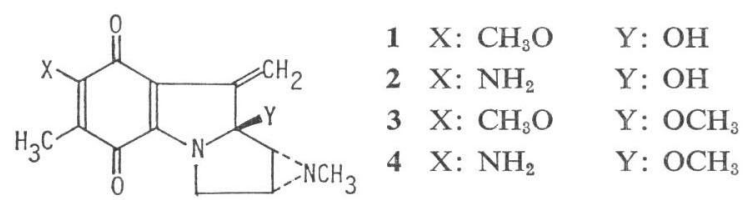

\begin{tabular}{l|ccccc}
\hline & \multicolumn{5}{c}{ MIC(mcg/ml) } \\
\cline { 2 - 6 } & $\mathbf{1}$ & $\mathbf{2}$ & $\mathbf{3}$ & $\mathbf{4}$ & Mitomycin B \\
\hline Vibrio percolans MB 1272 & 0.196 & 0.782 & 3.125 & 6.25 & $<0.025$ \\
Pseudomonas alcaligenes ATCC 12825 & $>50$ & $>50$ & $>50$ & $>50$ & 3.125 \\
Erwinia aroideae ATCC 15390 & 50 & 25 & $>50$ & $>50$ & 1.563 \\
Staphylococcus aureus ATCC 6538P & 0.782 & 3.125 & 6.25 & 50 & $<0.025$ \\
Escherichia coli No 26 & 50 & $>50$ & $>50$ & $>50$ & 6.25 \\
Bacillus subtilis ATCC 10707 & 0.098 & 0.098 & 0.391 & 0.196 & $<0.025$ \\
Proteus vulgaris ATCC 6897 & 6.25 & 1.563 & 50 & 50 & 0.098 \\
Shigella sonnei ATCC 9290 & $>50$ & 25 & $>50$ & $>50$ & 3.125 \\
Salmonella typhosa ATCC 9992 & 50 & $>50$ & $>50$ & $>50$ & 12.5 \\
Klebsiella pneumoniae ATCC 10031 & 12.5 & 3.125 & 12.5 & 12.5 & 0.196 \\
\hline
\end{tabular}


Fig. 3.

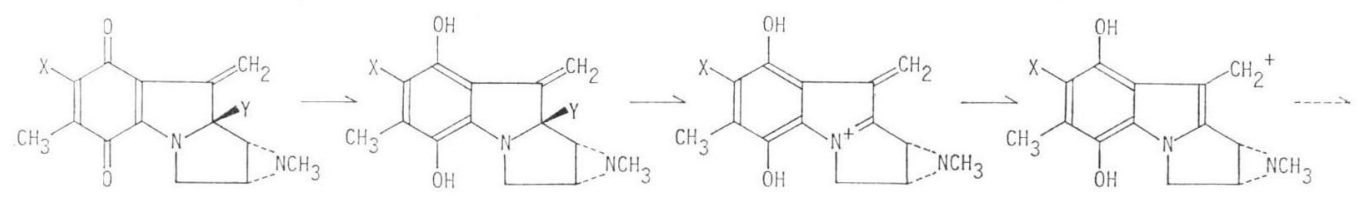

concentrations (MIC) by the agar dilution method. They showed weaker antibacterial activities than mitomycin B, although their antibacterial spectra were similar to that of mitomycin B. Compounds 1 and $\mathbf{2}$ showed stronger antibacterial activities than $\mathbf{3}$ and $\mathbf{4}$. It seems that in this series the 9a-hydroxy substituent provides stronger activity than the 9a-methoxy substituent. On the other hand, it appears that the effect of 7-substituent in the compounds upon antibacterial activity varies according to the kinds of bacteria.

As shown in Table 3, these compounds were strong growth inhibitors of $\mathrm{KB}$ cells. Among them, 2 was the most potent inhibitor. The $\mathrm{LD}_{50}$ value of 2 in mice (i.p.) was $210 \mathrm{mg} / \mathrm{kg}$ and its $\mathrm{ED}_{50}$ value to transplanted Sarcoma-180 A (solid type) in mice (i.p.-i.p.) was $82 \mathrm{mg} / \mathrm{kg}$. Therefore,

Table 3. Inhibition on the growth of $\mathrm{KB}$ cells in vitro by 10-decarbamoyloxy-9-dehydromitomycin $\mathrm{B}$ and its analogs.*

\begin{tabular}{c|ccccc}
\hline & $\mathbf{1}$ & $\mathbf{2}$ & $\mathbf{3}$ & $\mathbf{4}$ & $\begin{array}{c}\text { Mitomycin } \\
\mathrm{C}\end{array}$ \\
\hline $\mathrm{IC} \mathrm{C}_{50}(\mathrm{mcg} / \mathrm{ml})$ & 0.05 & 0.03 & 0.25 & 0.07 & 0.01 \\
\hline
\end{tabular}
these compounds are potential antitumor agents.

The mode of activation of these compounds, as shown in Fig. 3 could be similar to that of known mitomycins. ${ }^{2)}$

\section{Experimental}

Infrared spectra were determined in $\mathrm{KBr}$ disks on a Hitachi 215 spectrophotometer and proton nuclear magnetic resonance spectra were recorded on a Varian T-60 spectrometer and a JEOL FX-100 NMR spectrometer with tetramethylsilane as an internal standard. Mass spectra were determined on a JEOL-OISG-2 mass spectrometer. Thin-layer chromatography on silica gel (Merck Art. 5719) was carried out with a solvent system $\mathrm{CHCl}_{3}-\mathrm{Me}_{2} \mathrm{CO}(1: 1)$. The products were purified by column chromatography on silica gel (Merck Art. 7729).

10-Decarbamoyloxy-9-dehydromitomycin B (1)

To a solution of $100 \mathrm{mg}(0.287 \mathrm{mmole})$ of mitomycin B in $5 \mathrm{ml}$ of dry tetrahydrofuran was added $300 \mathrm{mg}$ of silica gel (Merck Art. 7729$)$ and $55 \mathrm{mg}$ (1.146 mmole) of sodium hydride ( $50 \%$ dispersion in mineral oil), and the reaction mixture was stirred at room temperature for two days. After addition of excess dry-ice, the suspension was filtered and the filtrate was evaporated under reduced pressure. The residue was subjected to gradient chromatography on silica gel with acetone - chloroform $(0: 1 \sim 1: 4)$. From the main blue fraction eluted a crude solid was obtained which was crystallized from acetone yielding $14 \mathrm{mg}(17.0 \%)$ of dark purple needles; Rf 0.70 ; IR $\nu_{\max } 3450,1660,1625,1560$; mass spectrum $\mathrm{M}^{+}$ 288.1086 (288.1110 calcd. for $\mathrm{C}_{15} \mathrm{H}_{10} \mathrm{~N}_{2} \mathrm{O}_{4}$ ).

7-Amino-10-decarbamoyloxy-9-dehydro-7-demethoxymitomycin B (2)

To a stirred mixture of $1 \mathrm{~g}\left(2.994\right.$ mmole) of 7-amino-7-demethoxymitomycin $\mathrm{B}^{3)}$ and $3 \mathrm{~g}$ of silica gel (Merck Art. 7729) in $50 \mathrm{ml}$ of dry tetrahydrofuran was added $480 \mathrm{mg}$ (10 mmole) of sodium hydride (50\% dispersion in mineral oil) at room temperature. The reaction mixture was stirred at room temperature for two days. After addition of excess dry-ice, the suspension was filtered and the filtrate was evaporated under reduced pressure. The residue was chromatographed on silica gel with acetone - chloro- 
form (1: 4). The main dark green fractions were combined. Evaporation gave $350 \mathrm{mg}(42.8 \%)$ of dark green needles; Rf 0.42; IR $\nu_{\max } 3400,1610,1535$; mass spectrum $\mathrm{M}^{+} 273.1118$ (273.1113 calcd. for $\mathrm{C}_{14} \mathrm{H}_{15} \mathrm{~N}_{3} \mathrm{O}_{3}$ ).

10-Decarbamoyloxy-9-dehydro- $N$-methylmitomycin A (3)

To a stirred solution of $20 \mathrm{mg}(0.069 \mathrm{mmole})$ of $1 \mathrm{in} 0.3 \mathrm{ml}$ of dry dimethylformamide and $1 \mathrm{ml}$ of dry benzene was added $20 \mathrm{mg}(0.417 \mathrm{mmole})$ of sodium hydride $(50 \%$ dispersion in mineral oil), followed by addition of $0.035 \mathrm{ml}$ of dimethyl sulfate at room temperature. After 2 minutes, to the reaction mixture were added $1 \mathrm{ml}$ of ethyl acetate saturated with water and an excess amount of dry-ice. The suspension was filtered and the filtrate was diluted with $10 \mathrm{ml}$ of ethyl acetate. The solution was washed with water and dried over anhydrous sodium sulfate. After removal of the solvent under reduced pressure, the residue was chromatographed over silica gel with acetone - chloroform (1:9). From the main bluishpurple fraction eluted were obtained dark purple needles, $8.7 \mathrm{mg}(41.5 \%)$; Rf 0.80; IR $\nu_{\max } 3450,2950$, 1650,1560 ; mass spectrum $\mathrm{M}^{+} 302.1280$ (302.1266 calcd. for $\mathrm{C}_{18} \mathrm{H}_{18} \mathrm{~N}_{2} \mathrm{O}_{4}$ ).

10-Decarbamoyloxy-9-dehydroporfiromycin (4)

To $5 \mathrm{ml}$ of methanol saturated with ammonia was added $10 \mathrm{mg}(0.033 \mathrm{mmole})$ of $\mathbf{3}$ and the solution was stirred at room temperature for 18 hours. The solution was evaporated under reduced pressure and crystallization of the residue from acetone - petroleum ether gave $6.2 \mathrm{mg}(65.2 \%)$ of green needles; Rf $0.63 ; \mathrm{IR} \nu_{\max } 3400,2950,1650,1610$; mass spectrum $\mathrm{M}^{+} 287.1252\left(287.1269\right.$ calcd. for $\mathrm{C}_{15} \mathrm{H}_{17} \mathrm{~N}_{3} \mathrm{O}_{3}$ ).

\section{Acknowledgments}

We would like to thank Mrs. M. Yoshida for recording $100 \mathrm{MHz}$ PMR spectrum, Miss Y. AdACHI for measuring mass spectra, Mrs. H. Suzuki for determining the antibacterial activity and Mr. T. AshizAwA for experimental assistance in the antitumor tests.

\section{References}

1) Urakawa, C.; H. Tsuchiya \& K. Nakano: New mitomycin, 10-decarbamoyloxy-9-dehydromitomycin B from Streptomyces caespitosus. J. Antibiotics 34: $243 \sim 244,1981$

2) IYer, V. N. \& W. Szybalski: Mitomycins and porfiromycin: Chemical mechanism of activation and crosslinking of DNA. Science 145: 55 58, 1964

3) Matsui, M.; Y. Yamada, K. Uzu \& T. Hirata： Studies on mitomycins. 3. The synthesis and properties of mitomycin derivatives. J. Antibiotics 21: 189 198, 1968

4) Urakawa, C.; K. NAKAno \& R. IMAI: Synthesis and biological activities of 7-alkoxymitosanes. J. Antibiotics 33: 804 809, 1980

5) Kinoshita, S.; K. Uzu, K. Nakano \& T. Takahashi: Mitomycin derivatives. 2. Derivatives of decarbamoylmitosane and decarbamoylmitosene. J. Med. Chem. 14: 109 112, 1971 